\title{
Pluviothermal Regionalization of Poland in Light of Present-Day Climate Change
}

\author{
Agnieszka Ziernicka-Wojtaszek* \\ Department of Ecology, Climatology and Air Protection, Faculty of Environmental Engineering and Land Surveying, \\ University of Agriculture in Kraków, Kraków, Poland
}

Received: 17 June 2018

Accepted: 25 November 2018

\begin{abstract}
This study presents three new regionalizations based on materials from 1971-2000 and from 1981-2010, and for an assumed scenario of a temperature increase of $1^{\circ} \mathrm{C}$. Heat resources are expressed in these regionalizations as sums of effective temperatures $\geq 10^{\circ} \mathrm{C}$, and water resources such as Sielianinov's hydrothermal coefficient $\mathrm{K}$ from June to August. An increase was found in the area of the moderately warm region with a sum of temperatures $\geq 10^{\circ} \mathrm{C}$ from $61 \%$ in $1931-1960$ to $62 \%$ in $1971-2000,87 \%$ in the 30 -year period $1981-2010$, and $73 \%$ for the scenario with the assumed $1{ }^{\circ} \mathrm{C}$ temperature increase. In the last case, a new thermal region appeared: a warm region with a sum of temperatures $\geq 10^{\circ} \mathrm{C}$ in the range of $2800-3200^{\circ} \mathrm{C}$, covering almost the entire remaining area of the country. As warming progresses, in the absence of clear tendencies for atmospheric precipitation, the climate in Poland is becoming increasingly dry. Areas classified as dry with a hydrothermal coefficient of 1.0-1.3 increased from $13 \%$ of the area of the country in $1931-1960$ to $20 \%$ in the 30 -year period $1971-2000,46 \%$ in the 30 -year period $1981-2010$, and $65 \%$ for the scenario with a $1{ }^{\circ} \mathrm{C}$ temperature increase.
\end{abstract}

Keywords: contemporary climate change, temperature, precipitation, regionalization, Poland

\section{Introduction}

Due to the natural variability of weather in different years, in accordance with the recommendations of the World Meteorological Organization and its predecessor, the International Meteorological Organization (1873-1947), characterization of the climate has been based on multiyear, usually 30-year periods, beginning with 1901-1930 [1]. In Poland, these have been the 30-year periods 1931-1960 [2] and 1961-1990 [3], as well as longer periods of 40 years

*e-mail: agnieszka.ziernicka-wojtaszek@urk.edu.pl
(1891-1930) for precipitation [4] and 50 years (1881-1930) for air temperature [5]. In view of the marked increase in air temperature, especially in the last two decades of the 20th century [6-10 and successive IPCC reports], amounting to $0.2^{\circ} \mathrm{C}$ per decade on a global scale and $0.3^{\circ} \mathrm{C}$ in Poland, the sense of using climate normals calculated in this manner to characterize current climatic conditions, and even more so future conditions, has increasingly come under question [11].

The pace of global warming is clearly increasing. According to the IPCC's Fourth Assessment Report, it was only $0.045^{\circ} \mathrm{C}$ per decade in the last 150 years, and then $0.074^{\circ} \mathrm{C} /$ decade in the last century, increasing to $0.128^{\circ} \mathrm{C} /$ decade in the last 50 years, to 
reach $0.177^{\circ} \mathrm{C} /$ decade in the last 25 years. The data for the years 1979-2012 published in the Fifth Assessment Report indicate even higher values of $0.26^{\circ} \mathrm{C} /$ decade [12-15]. A practical expression of taking climate change into account was the replacement of the 1961-1990 normal with the average from 1971-2000, and currently the value for 1981-2010, and a report summarizing the warmest decade in the history of instrumental observations, i.e., 2001-2010 [16]. In 2021 a new 30year base period will begin, covering the mean from 1991-2020.

In Poland, marked warming has been observed since the last two decades of the $20^{\text {th }}$ century. While authors analysing material from the first half of the $20^{\text {th }}$ century pointed out the occurrence of increasingly warm winters, since the last two decades of the $20^{\text {th }}$ century they have drawn attention to evident warming not only in the winter and spring, but also in the summer [10, 17, 18]. Warming in Poland in 1981-2010, amounting to $0.33^{\circ} \mathrm{C}$ per decade, is mainly due to the increase in temperature in the summer and spring. The greatest increase in temperature takes place in July and April, and a somewhat smaller increase in June and August. Due to the increase in air temperature, the length of the meteorological growing season (from $\geq 5^{\circ} \mathrm{C}$ ) has increased as well and conditions for thermophilous plants have improved.

Global warming is not only an agrometeorological problem - the lengthening of the meteorological growing period and the possibility of cultivating thermophilous plants - but most importantly entails changes in freshwater-resources, which are likely to have more significant consequences than the increase in temperature itself. Climatic resources expressed as the values of individual elements or climatic indices, as well as composite indices, have spatial variation determined by geographical climate factors and are expressed graphically on maps, usually using isolines. In Witek and Górski's [19] valuation of the agricultural production space of Poland, based on material from 1958-1967, the authors deliberately did not attempt an agroclimatic regionalization understood as a delimitation of distinct climate regions, as they believed that spatial variation of all climate elements is of a continuous nature, so that there is an infinite number of equally valid divisions. However, most authors dealing with variation in the climate or agroclimate of Poland, such as Gumiński [20], Romer [21], Schmuck [22], Cherszkowicz [23], or Bac [24], distinguish such regions. In contemporary studies on the consequences of climate change for agricultural production for the whole of Europe, Poland is included in the northeastern region, which also includes the Czech Republic and Slovakia [25], or in a continental zone covering an area that is slightly wider to the east and southeast of the aforementioned region [26]. These are approaches on a continental scale, concerning climate variation according to the degree of suitability for agriculture. The present study is on the scale of a single country and concerns the division of a country, in this case Poland, into smaller climate units.

The subject of the study is the evolution of regional variation in pluviothermal conditions in Poland from the second half of the $20^{\text {th }}$ century to the first decade of the $21^{\text {st }}$ century, with an observed increase in air temperature but no clear trends in precipitation. The aim of the study is to show the increase in the area of warm and dry areas as global warming progresses.

\section{Material and Methods}

The source data were the average monthly air temperature values and monthly precipitation totals from 1971-2010, obtained from PIHM and IMGW published and archival data. The data were from 53 meteorological stations distributed evenly across Poland. Mountain areas were omitted in the study due to the small number of meteorological stations located in these areas. The materials have been verified and in some cases the method of finite differences was used. Thermal conditions for the growing season were characterized by the sum of effective temperature $\geq 10^{\circ} \mathrm{C}$, and the humidity conditions by Sielianinov's hydrothermal coefficient $\mathrm{K}$ for June-August. The sum of temperatures $\geq 10^{\circ} \mathrm{C}$ was calculated on the basis of long-term average air temperatures following prior determination of the dates when the temperature passed the $10^{\circ} \mathrm{C}$ threshold.

Three thermal regions were distinguished with a temperature sum $\geq 10.0^{\circ} \mathrm{C}$ in ranges of $2000-2400^{\circ} \mathrm{C}$, $2400-2800^{\circ} \mathrm{C}$ and $2800-3200^{\circ} \mathrm{C}$, designated as moderately cool, moderately warm and warm, and three humidity regions, with hydrothermal coefficient $\mathrm{K}<1.3$, 1.3-1.6 and $>1.6$, designated as moderately dry, optimum humidity, and humid. The $\mathrm{K}$ coefficient, as in the study by Cherszkowicz [23], was calculated for the period from June to August according to the formula $\mathrm{K}=10 \mathrm{P} / \mathrm{t}$, where $\mathrm{P}$ is the precipitation total and $\mathrm{t}$ is the sum of daily air temperature values, which was calculated after prior establishment of the dates when the temperature passed the $10^{\circ} \mathrm{C}$ threshold.

Three regionalizations of Poland's climate based on thermal and precipitation criteria were presented for the periods 1971-2000, 1981-2010, and the assumed scenario of $+1^{\circ} \mathrm{C}$ with respect to $1981-2010$. The results of the study were compared with the study by Cherszkowicz [23] using the same method for the earliest period, 1931-1960, before evident climate warming.

\section{Results and Discussion}

In the period 1931-1960 analysed by Cherszkowicz [23] the northern part of Poland, i.e., the Baltic Coast and the Pomeranian Lakeland, together with small areas including the Świętokrzyskie Mountains and the lower parts of the Carpathian Mountains and Sudetes, covering a total area of $39 \%$ of Poland, is occupied 


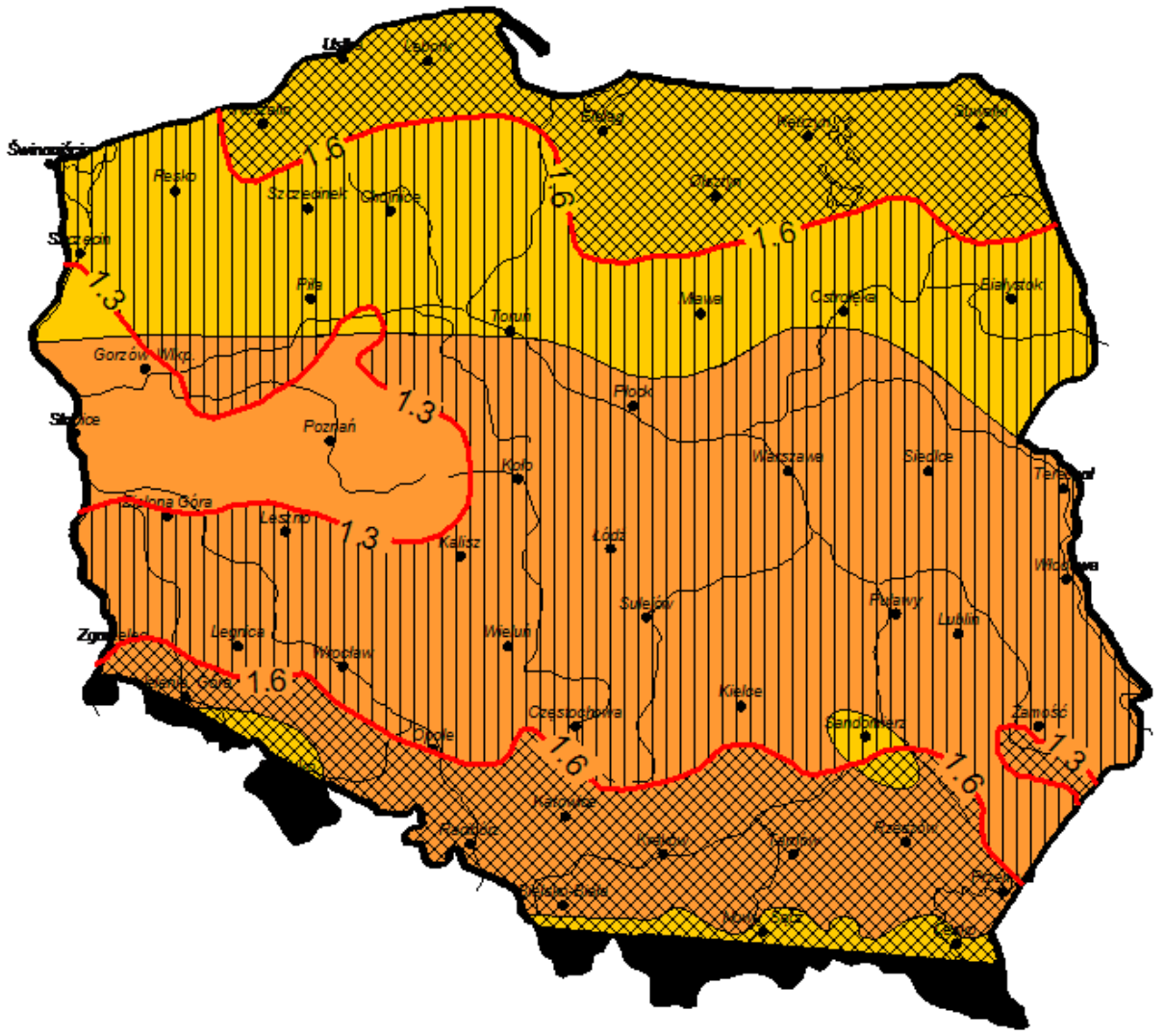

\begin{tabular}{|c|c|c|c|}
\hline Thermal regions & Temperature sum $\geqslant 10^{\circ} \mathrm{C}$ & Humidity regions & Hydrothermal coefficient \\
\hline Cool & \begin{tabular}{|l}
$\square \quad 1600^{\circ}-2000^{\circ}$ \\
\end{tabular} & Moderately dry & $1.0-1.3$ \\
\hline Moderately cool & $2000^{\circ}-2400^{\circ}$ & Optimum humidity & $\begin{array}{l}1.0-1.5 \\
1.3-1.6\end{array}$ \\
\hline Moderately warm & $2400^{\circ}-2800^{\circ}$ & Optimunt num unty & $\frac{11}{8 x}>1.6$ \\
\hline Warm & $2800^{\circ}-3200^{\circ}$ & Humid & \\
\hline
\end{tabular}

Fig. 1. Pluviothermal regions in Poland in 1931-1960.

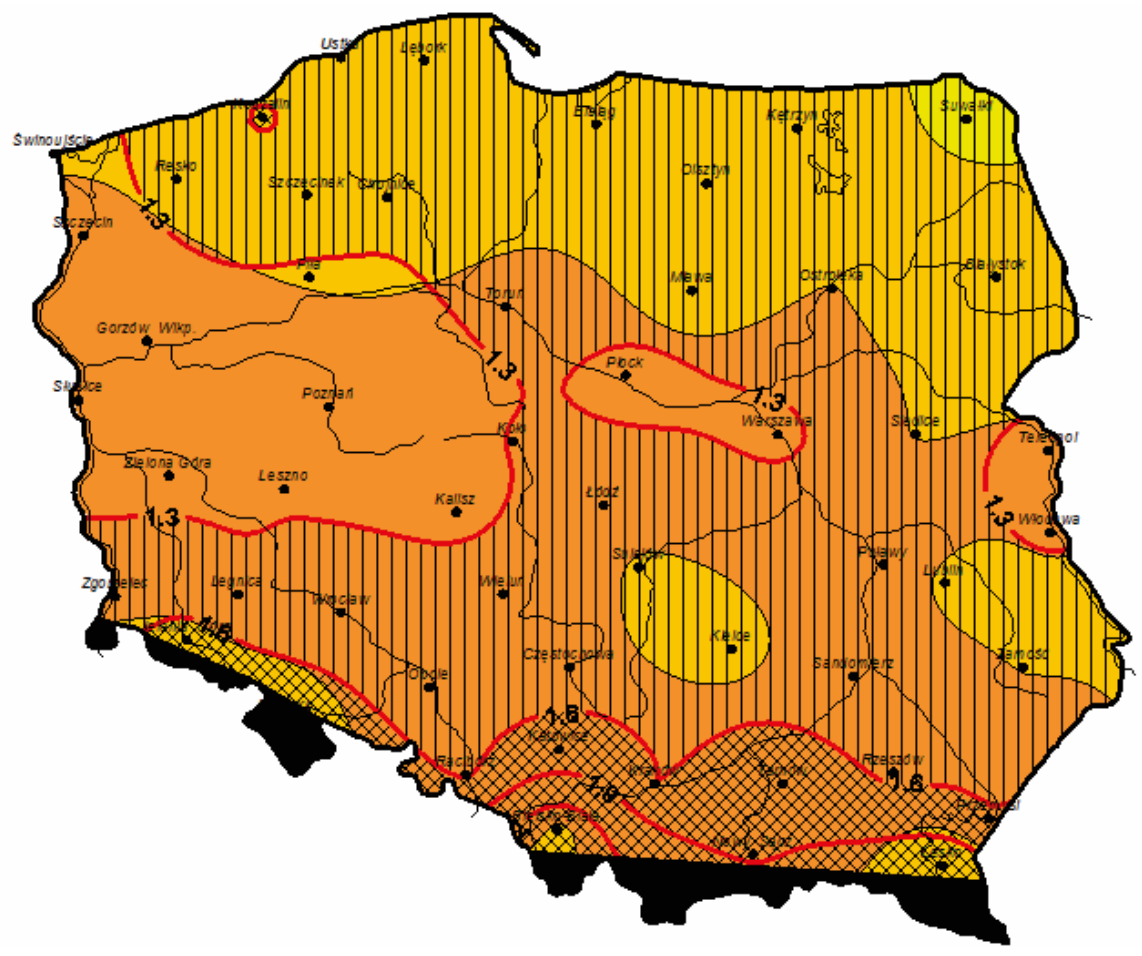

Fig. 2. Pluviothermal regions in Poland in 1971-2000. Legend: as for Fig. 1. 
by a moderately cool region with a temperature sum of $2000-2400^{\circ} \mathrm{C}$. The rest of central and southern Poland, with a surface area of $61 \%$, is occupied by a moderately warm region with an average temperature of $2400-2800^{\circ} \mathrm{C}$ (Fig. 1).

In the period 1971-2000, with a marked increase in air temperature, especially since the last two decades of the $20^{\text {th }}$ century, the area of the moderately cool region, generally in the northern and northeastern parts of Poland, decreases to $37 \%$. At the same time, the moderately warm region, with a temperature sum $\geq 10^{\circ} \mathrm{C}$ of $2400-2800^{\circ} \mathrm{C}$, increases to $62 \%$. The area of the driest region, designated as moderately dry, with a hydrothermal coefficient $\mathrm{K}$ ranging from 1.0 to 1.3 , increases from $13 \%$ to $20 \%$ of the area of the country and initially covers only the west-central part of Poland (Fig. 2).

In the period 1981-2010, the area of the moderately cool region decreased to $14 \%$ and thus the area of the moderately warm region increased to $87 \%$ as compared to the period 1971-2000. The area of the moderately dry region increased to $46 \%$ (Fig. 3).

With a temperature rise of $1^{\circ} \mathrm{C}$, the moderately cool region is clearly vanishing, while a warm region appears, in which the sum of temperatures $\geq 10^{\circ} \mathrm{C}$ reaches values between $2800^{\circ} \mathrm{C}$ and $3200^{\circ} \mathrm{C}$, and occupies $26.1 \%$ of Poland. This region is located in the southwestern part of Poland, with the exception of the Sudeten Foothills and Sudeten Mountains (Fig. 4).
With respect to humidity conditions, the warm region can be divided into the following parts:

1) Moderately dry - occupying $17.2 \%$ of Poland, which will be in the western part of the Wielkopolska Lakeland and the Wielkopolska Lowland. This includes small areas in the vicinity of Pulawy and Sandomierz.

2) Optimum humidity - occupying $7.1 \%$ of Poland, which will be in the southeastern part of the Silesian Lowland, the western parts of the Silesian Upland, the southeastern part of the Małopolska Upland and the southern parts of the Sandomierz Basin.

3) Humid - occupying $1.8 \%$ of Poland, located in the Carpathian Mountain range in the vicinity of Nowy Sącz (Fig. 4).

In other parts of Poland we can distinguish a moderately warm and moderately dry region, a moderately warm region with optimal humidity, and a moderately warm and humid region. The moderately warm and moderately dry region, occupying $48 \%$ of Poland, will be in the western part of the Baltic Coast, in the southern parts of the Pomeranian Lake District, in the northern part of the Wielkopolska Lakeland, in the Mazovian Lowland, and in the Lublin Upland (Fig. 4).

The moderately warm region with optimum humidity, occupying $22 \%$ of Poland, will be in the central and eastern parts of the Baltic Coast, the northern regions of the Pomeranian and Masurian Lake Districts, and also in the Sudeten Foothills, the eastern

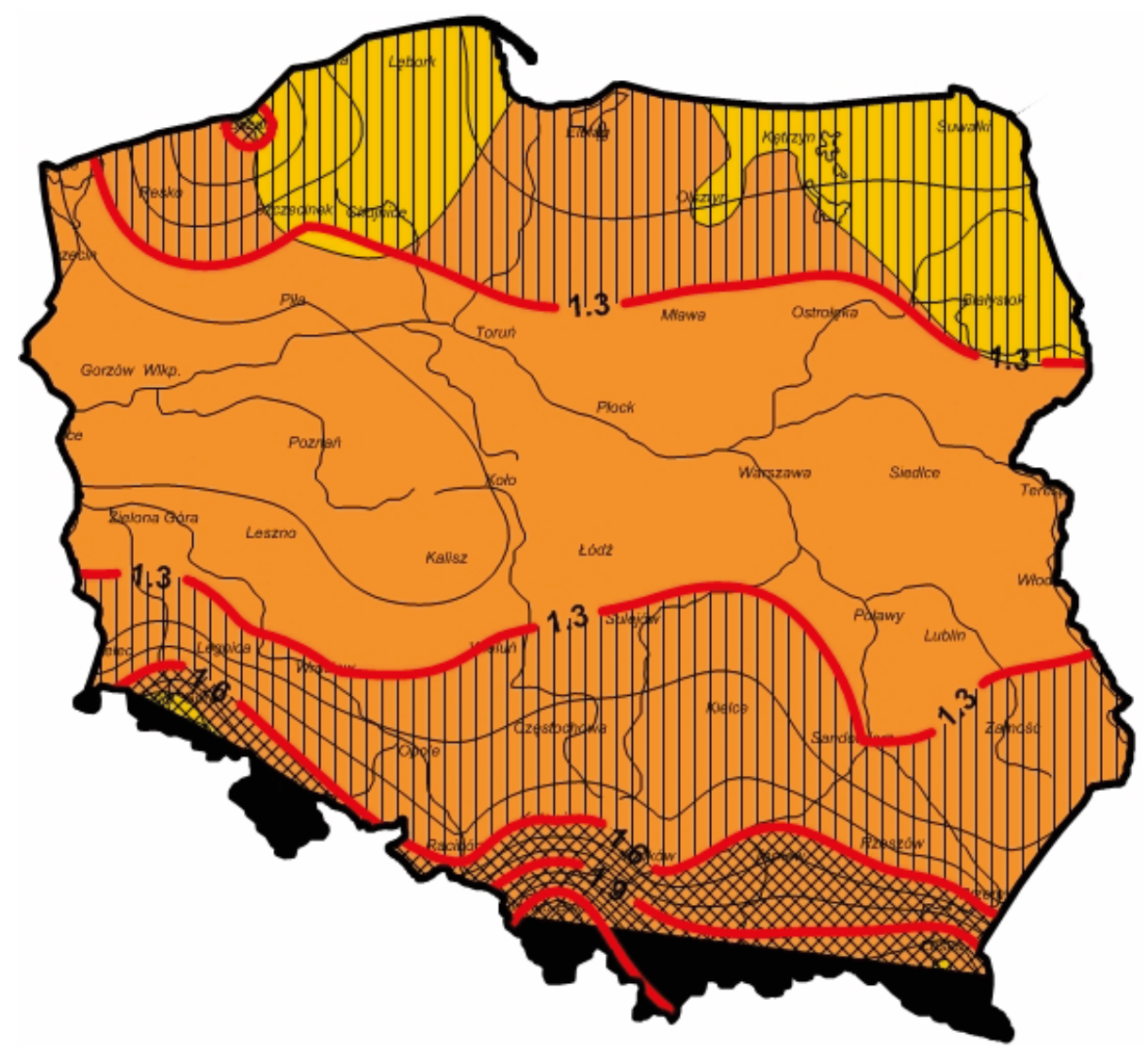

Fig. 3. Pluviothermal regions in Poland in 1981-2010. Legend: as for Fig. 1. 


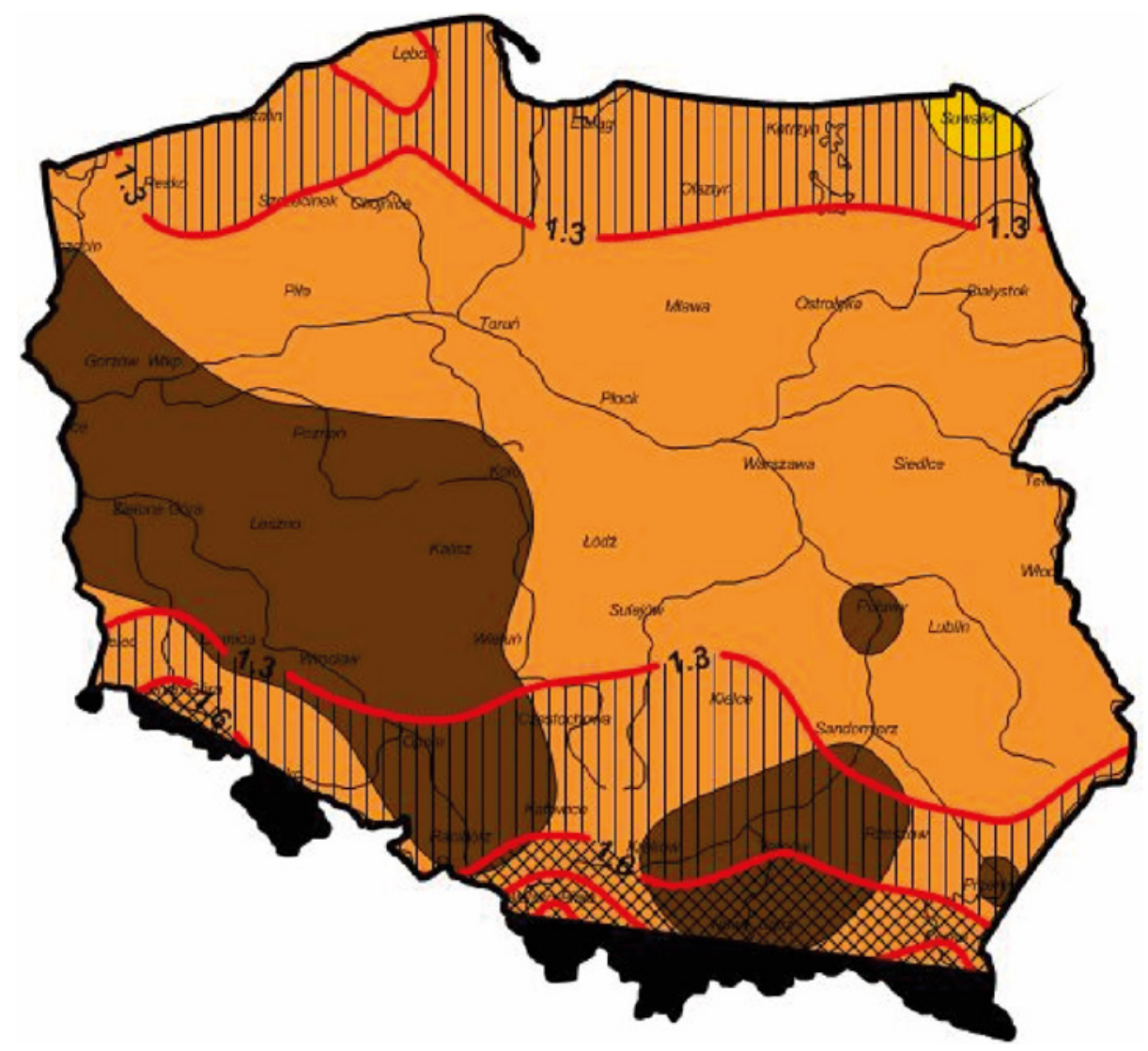

Fig. 4. Pluviothermal regions for a scenario assuming an air temperature increase of $1^{\circ} \mathrm{C}$ with respect to 1981-2010. Legend: as for Fig. 1.

part of the Silesian Upland, and the western part of the Małopolska Upland and Sandomierz Basin (Fig. 4).

The moderately warm and humid region, occupying $2.8 \%$ of Poland, will be in the Beskidy Mountains, Carpathian Foothills and Sudetes (Fig. 4).

The agroclimatic regionalization of Poland presented here is a general regionalization that does not take into account the requirements of specific groups or species of crops. The main motivation for conducting the research by assessing the thermal conditions for plant growth using the effective sum of temperatures $\geq 10^{\circ} \mathrm{C}$ and humidity conditions using Sielianinov's hydrothermal coefficient for the period from June to August was the existence of such a study based on materials from 1931-1960, and thus prior to pronounced climate warming [23]. To track changes in the range and area of pluviothermal regions, two periods recommended by the World Meteorological Organization as climate normals were chosen, i.e., 1971-2000 (the old, previous normal) and 1981-2010 as the new normal. The third regionalization for the temperature increase of $1^{\circ} \mathrm{C}$ was chosen as one of the possible options for a further step in time. Assuming a warming rate of $0.33^{\circ} \mathrm{C}$ per decade for the period 1981-2010 for Poland, such a state would be 10 years ahead of the publication of the study, i.e., 2028.

Mountain areas were omitted from the regionalization. It is not precisely possible to assess contemporary climate change in Polish mountains due to the lack of long-term meteorological observations in this area, the elimination of a large number of meteorological stations in recent decades and the lack of current regional studies of the contemporary climate of mountain areas. As the fundamental causes of global warming are of a global nature, it is possible to use research from neighbouring lowland areas and other mountain areas of Europe [27], as well as results from the few Polish mountain stations [28]. For the Carpathian Mountains, the work of [29] for Slovakia on agroclimate regionalization of viniculture for selected climate change scenarios can be used with some degree of approximation. A key issue in the characterization of climate change in mountainous areas is assessing how high the traditional vertical climate zones have risen during the period of marked climate warming, which can be considered to be the last two decades of the $20^{\text {th }}$ century and the start of the $21^{\text {st }}$ century.

Although agriculture as a sector of the economy has always been strongly dependent on the variable weather conditions each year, in 2005 the issue of climate change was still not included in the Rural Development and Agriculture Strategy for 2007-2013 as prepared by the Ministry of Agriculture and Rural Development (with elements of prognosis up to 2020). This need is acknowledged in the document developed by the Institute of Environmental Protection - National Research Institute in 2013, titled 'Adaptation of sensitive sectors and areas of Poland to climate change by 2070 '. 
Table 1. The area of designated pluviothermal regions for mean values for the period 1931-1960, 1971-2000, 1981-2010 and a scenario assuming an air temperature increase of $1^{\circ} \mathrm{C}$ with respect to $1981-2010$ (given as $\%$ of the Poland area).

\begin{tabular}{|c|c|c|c|c|c|}
\hline \multirow[b]{2}{*}{ Period } & \multirow[b]{2}{*}{$\begin{array}{l}\text { Humidity region and hydro- } \\
\text { thermal coefficient }\end{array}$} & \multicolumn{4}{|c|}{ Thermal region and effective temperature sums $\geq 10^{\circ} \mathrm{C}$} \\
\hline & & $\begin{array}{c}\text { Cool } \\
1600-2000\end{array}$ & $\begin{array}{c}\text { Moderately cool } \\
2000-2400\end{array}$ & $\begin{array}{l}\text { Moderately warm } \\
2400-2800\end{array}$ & $\begin{array}{c}\text { Warm } \\
2800-3200\end{array}$ \\
\hline \multirow{3}{*}{$1931-1960$} & Moderately dry 1.0-1.3 & & 1 & 12 & \\
\hline & Optimal humid 1.3-1.6 & & 18 & 37 & \\
\hline & Humid $>1.6$ & & 20 & 12 & \\
\hline \multirow{3}{*}{$1971-2000$} & Moderately dry $1.0-1.3$ & & 1 & 19 & \\
\hline & Optimal humid 1.3-1.6 & 1 & 33 & 36 & \\
\hline & Humid $>1.6$ & & 3 & 7 & \\
\hline \multirow{3}{*}{$1981-2010$} & Moderately dry $1.0-1.3$ & & 0.3 & 46 & \\
\hline & Optimal humid 1.3-1.6 & & 13 & 33.5 & \\
\hline & Humid $>1.6$ & & 0.2 & 7 & \\
\hline \multirow{3}{*}{$\begin{array}{c}\text { Scenario assuming an } \\
\text { air temperature increase } \\
\text { of } 1^{\circ} \mathrm{C} \text { with respect to } \\
1981-2010\end{array}$} & Moderately dry $1.0-1.3$ & & & 48 & 17.2 \\
\hline & Optimal humid 1.3-1.6 & & 1.1 & 22 & 7.1 \\
\hline & Humid $>1.6$ & & & 2.8 & 1.8 \\
\hline
\end{tabular}

The document shows that the problem of adaptation of individual sectors of the Polish economy to climate change is still new, and uncertainty about the size and direction of these changes and their consequences is so great that research in this area must be undertaken and continued.

One of the research directions that climate warming has given rise to is the possibility of growing thermophilous plants in Poland, especially grapevines $[30,31]$. Other positive characteristics of warming include the prolongation of the meteorological growing period, indicated in numerous publications [32-34].

But global climate change is not just global warming. Changes in freshwater resources appear to be more important than the rise in temperature in terms of their consequences [35]. The increase in evapotranspiration due to the increase in air temperature, in the absence of clear trends in precipitation in Poland, means that the negative consequences of climate change outweigh the expected benefits. For this reason pluviothermal regionalizations in which water resources are not associated with thermal resources are unsuitable for detecting changes in water resources. Despite the increase in air temperature, they will not show the decrease in water resources.

Cherszkowicz's regionalization [23], on the other hand, where heat resources are expressed as the sum of active temperatures $\geq 10^{\circ} \mathrm{C}$ and water resources are expressed by a hydrothermal coefficient relating precipitation to air temperature, is perfectly suited for this. This is not the only method for detecting regional changes in water resources. Any thermal-humidity regionalizations in which water resources are expressed by water balance values are also very well suited for this.
Water balance can be calculated in very different ways, such as Palmer's method or standardized precipitation [36, 37]. Another example is a study by ZiernickaWojtaszek and Zawora [38], which estimated the changes in thermal resources and the climatic water balance in Poland in two successive normal periods recommended by the World Meteorological Organization (WMO), 1971-2000 and 1981-2010. Thermal resources were defined by the temperature sum, and the climatic water balance was calculated as the difference between the precipitation sum and the sum of potential evaporation, determined by the Thornthwaite method (1948).

A novel aspect of the study is the image of pluviothermal regions for agricultural purposes for the new 1981-2010 normal, for which we do not yet have an officially published Climatic Atlas of Poland. The latest published Lorenc Atlas [39] pertains to the old 1971-2000 period.

To sum up, the research results, despite different methods and periods, are generally consistent with the picture of changes in agroclimatic conditions diagnosed for central Europe for the period 1961-1990 and selected climate change scenarios for 2020 and 2050 [40]. The research shows that over the past few decades the assumption that the agroclimatic conditions of this area remain relatively stable has been undermined by ongoing climate change. Initially, elevated air temperature leads to a prolonged growing season and significant shifts in agroclimatic zones. Areas that are currently the most productive will be reduced and replaced by regions with warmer but drier conditions. At the same time, there is a risk, as water shortages are becoming relatively frequent in places where they had not previously occurred. The pace of the changes may be so rapid 
that area development planning for agriculture taking into account climatic conditions may quickly become obsolete, due to the rapid and continuous change in heat and moisture conditions.

\section{Conclusions}

1) The increase in the mean area annual air temperature in the last three decades in Poland is estimated at about $0.3^{\circ} \mathrm{C}$ per decade. In the years $1971-1980$ the mean annual air temperature was $7.6^{\circ} \mathrm{C}$. In the decade $1981-1990$ it increased to $8.0^{\circ} \mathrm{C}$. In the years 1991-2000 the average annual temperature had already reached $8.3^{\circ} \mathrm{C}$, and in $2001-2010$ it was as high as $8.6^{\circ} \mathrm{C}$.

2) A consequence of the increase in air temperature is the systematic decrease in the area of the moderately cool region with a sum of temperatures $\geq 10^{\circ} \mathrm{C}$ within the range $2000-2400^{\circ} \mathrm{C}$, from $39 \%$ in $1931-1960$ to $37 \%$ in $1971-2000$ and $14 \%$ in the 30 -year period of 1981-2010.

3) With the decreasing surface area of the moderately cool region there is an increase in the area of the moderately warm region with the sum of temperatures $\geq 10^{\circ} \mathrm{C}$ in the range of $2400-2800^{\circ} \mathrm{C}$, from $61 \%$ in $1931-1960$ to $62 \%$ in $1971-2000$ and $87 \%$ in $1981-2010$.

4) As climate warming progresses, in the absence of clear precipitation trends, the climate of Poland is becoming more arid. Areas classified as dry with a hydrothermal coefficient of 1.0-1.3 increased their surface area from $13 \%$ in the period $1931-1960$ to $20 \%$ in the 30 -year period of $1971-2000$, and $46 \%$ in the 30-year period of 1981-2010.

5) Global warming initially improved the humidity conditions in Poland, as the area of the optimum humidity region increased from $55 \%$ to $70 \%$ in the periods of 1931-1960 and 1971-2000. In the 30-year period of 1981-2010, the optimum humidity region decreased to $47 \%$.

6) With an assumed $1{ }^{\circ} \mathrm{C}$ increase in air temperature as compared to the current 1981-2010 normal, the moderately warm region with a sum of temperatures $\geq 10^{\circ} \mathrm{C}$ in the range of $2400-2800^{\circ} \mathrm{C}$ will cover almost $73 \%$ of the area of Poland. There will also be a new thermal region - warm with a sum of temperatures $\geq 10^{\circ} \mathrm{C}$ in the range of $2800-3200^{\circ} \mathrm{C}$, covering almost all of the rest of the country. The area of the dry region will increase to more than $65 \%$ and the optimum humidity region will decrease to slightly over $30 \%$.

7) The region most vulnerable to drought due to progressive warming and decreasing precipitation efficiency is the southwestern part of Poland, with the lowest precipitation - especially in the warmer half of the year, the highest temperature, and the highest values for the hydrothermal coefficient. In particular, this is the southwestern part of the Pomeranian
Lakeland, the Wielkopolskie Lakeland, the South Wielkopolska Lowland and the Silesian Lowland.

8) Further detailed research is required to establish which areas are most vulnerable to the negative effects of drought caused by the increase in air temperature due to global warming, where adaptation measures should be undertaken first. The present study focused more on the problem of the expansion of the dry zone rather than the intensification of drought in the regions that have been the driest to this point.

\section{Acknowledgements}

The research was carried out under Project No. DS-3337/KEKiOP/2018 financed from a research grant allocated by the Ministry of Science and Higher Education.

\section{Conflict of Interest}

The authors declare that they have no conflict of interest.

\section{References}

1. ARGUEZ A., VOSE R.S. The Definition of the Standard WMO Climate Normal: The Key to Deriving Alternative Climate Normals. Bull. Amer. Meteor. Soc., 92, 699, 2011.

2. WISZNIEWSKI W. The Climate Atlas of Poland. The Institute of Meteorology and Management, The Polish Cartographic Publishers, Warszawa, 1973 [In Polish].

3. KOSSOWSKA-CEZAK U., MARTYN D., OLSZEWSKI K., KOPACZ-LEMBOWICZ M. Meteorology and Climatology. Measurements, observations, studies. PWN, Warszawa-Łódź, 1, 2000 [In Polish].

4. WISZNIEWSKI W. Atlas of Precipitation in Poland 18911930. PIHM, WK, Warszawa, 1953 [In Polish].

5. WISZNIEWSKI W., GUMIŃSKI R., BARTNICKI L. Monographs on the Climatology of Poland. Data gathered by the National Hydrological and Hydrogeological Services, 1, 5, 27, Warszawa, 1949 [In Polish].

6. KOŻUCHOWSKI K., ŻMUDZKA E. Climate Warming in Poland: the Range and Seasonality of the Changes in Air Temperature in the Second Half of the $20^{\text {th }}$ Century. Polish Geographical Review, 46, 81, 2001 [In Polish].

7. SOLOMON S., QIN D., MANNING M., CHEN Z., MARQUIS M., AVERYT K.B., TIGNOR M., MILLER H.L. Climate Change 2007: The Physical Science Basis. Cambridge University Press: 1-996, 2007.

8. MILLY P.C.D., BETANCOURT J., FALKENMARK M., HIRSCH R.M., KUNDZEWICZ Z.W., LETTENMAIER D.P., STOUFFER R.J. Stationarity is Dead: Whither Water Management. Science, 319 (5863), 573, 2008.

9. ŻMUDZKA E. Contemporary Changes of Climate of Poland. Acta Agroph., 13 (2), 555, 2009 [In Polish].

10. WÓJCIK R., MIĘTUS M. Some Features of Long-Term Variability in Air Temperature in Poland (1951-2010). Polish Geographical Review, 86, 3, 339, 2014 [In Polish]. 
11. LIVEZEY R.E., VINNIKOV K.Y., TIMOFEYEVA M.M., TINKER R., VAN DEN DOOL H.M. Estimation and Extrapolation of Climate Normals and Climatic Trends. J. Appl. Meteor. Climatol., 46, 1759, 2007.

12. HANSEN J., RUEDY R., SATO M., LO K. Global Surface Temperature Change. Rev. Geophys., 48 (4), 1, 2010, RG4004.

13. LAWRIMORE J.H., MENNE M.J., GLEASON B.E., WILLIAMS C.N., WUERTZ D.B., VOSE R.S., RENNIE J. An Overview of the Global Historical Climatology Network Monthly Mean Temperature Data Set, version 3. J. Geophys. Res. Atmos., 116, 2011, D19121.

14. JONES P.D., LISTER D.H., OSBORN T.J., HARPHAM C., SALMON M., MORICE C.P. Hemispheric and LargeScale Land-Surface Air Temperature Variations: An Extensive Revision and an Update to 2010. J. Geophys. Res. Atmos., 117, 2012, D05127.

15. ROHDE, R., MULLER R.A., JACOBSEN R., MULLER E., PERLMUTTER S., ROSENFELD A., WURTELE J., GROOM D., WICKHAM C. A New Estimate of the Average Earth Surface Land Temperature Spanning 1753 to 2011. Geoinfor. Geostat.: An Overview, 1, 2013.

16. JARRAUD M. WMO Report: The Global Climate 2001-2010: A Decade of Climate Extremes. July 6, 2013.

17. MICHALSKA B. Variability of Air Temperature in North Western Poland (In.) Szwejkowski Z. (eds.) Environmental Aspects of Climate Change. UW-M, Olsztyn, 89, 2009 [In Polish].

18. ŻMUDZKA E. Changes in Thermal Conditions in the High Mountain Areas and Contemporary Warming in the Central Europe. Miscellanea Geographica, 14, 59, 2010 [In Polish].

19. WITEK T., GORSKI T. Assessment of the Natural Value of Agricultural Areas in Poland. Wyd. Geol., Warszawa, 1977 [In Polish].

20. GUMIŃSKI R. An Attempt to Separate Agricultural Climate Areas in Poland. Prz. Meteor. i Hydrol., 1, 7, 1948 [In Polish].

21. ROMER E. Climatic Regions of Poland. Pr. Wroc. Tow. Nauk., Ser. B, 16, 1949 [In Polish].

22. SCHMUCK A. Pluviothermal Regions in Poland. Geographical Journal, 36, 3, 239, 1965 [In Polish].

23. CHERSZKOWICZ E. Agro and Climate Related Region Taxonomy for Fundamental Crops' Cultivation in the Socialist European Countries. Bulgarian Academy of Sciences: Sofia, 1, 1971 [In Russian].

24. BAC S. Assessment of Climate Conditions for Agricultural Purposes. Acta Univ. Wratisl., 1237, Pr. Inst. Geogr., 6, 5, 1991 [In Polish].

25. OLESEN J.E., BINDI M. Consequences of Climate Change for European Agricultural Productivity, Land Use and Policy. Europ. J. Agronomy, 16, 239, 2002.

26. OLESEN J.E., TRNKA M., KERSEBAUM K.C., SKJELVÅG A.O., SEGUIN B., PELTONEN-SAINIO P., ROSSI F., KOZYRA J., MICALE F. Impacts and
Adaptation of European Crop Production Systems to Climate Change. Europ. J. Agronomy, 34, 96, 2011.

27. MIGAŁA K. Vertical Climate Zones in the Mountains of Europe and the Problem of Global Changes. Acta Universitatis Wratislaviensis, 2718, Studia Geograficzne 78, 149, 2011 [In Polish].

28. ŻMUDZKA E. Contemporary Climate Changes in the High Mountain Part of the Tatras. Studies in Geography, 47, 217, 2011 [In Polish].

29. ŠPÁNIK F., HRONSKÝŠ .,ŠIŠKA B., GÁLIK M. Global Warming as a Basis for a New - 226. Agroclimatic Regionalisation of Vine in Slovakia. Acta Agroph., 3 (1), 179, 2004

30. ŻMUDZKA E. Long-term Changes of Thermal Resources in the Vegetative Period and the Active Growth of Plants in Polsce. Water-Environment-Rural-Areas, 12, 2 (38), 377, 2012 [In Polish].

31. KRUŻEL J. Ecological and Economic Consequences of Contemporary Changes of Thermal Features of the Climate of Poland (1971-2010). Master's thesis performed in Chair of Ecology, Climatology and Air Protection. Supervisor dr hab. inż. Agnieszka Ziernicka-Wojtaszek, 2014 [In Polish].

32. NIERÓBCA A., KOZYRA J., MIZAK K., WRÓBLEWSKA E. Changes in the Length of Growing Season in Poland. Water-Environment-Rural-Areas, 13, 2, (42), 81, 2013 [In Polish].

33. KRUŻEL J., ZIERNICKA-WOJTASZEK A., BOREK Ł., OSTROWSKI K. The Changes in the Duration of the Meteorological Vegetation Period in Poland in the Years 1971-2000 and 1981-2010. Ecological Engineering, 44, 47, 2015 [In Polish].

34. TOMCZYK A.M., SZYGA-PLUTA K. Growing Seasons in Poland in the Period 1971-2010. Polish Geographical Review, 88, 1, 75, 2016 [In Polish].

35. IWANICKI J., KINDLER J., KUNDZEWICZ Z.W Hazards Related to Water. Science, 1, 63, 2014 [In Polish].

36. ALLEY W.M. The Palmer Drought Severity Index: Limitations and Assumptions. Journal of Climate and Applied Meteorology, 23, 1100, 1984.

37. ŁABĘDZKI L., BĄK B. Monitoring of Droughts Using the Standardized Precipitation Index SPI. Water-EnvironmentRural-Areas, 2, 2 (5), 9, 2002 [In Polish].

38. ZIERNICKA-WOJTASZEK A., ZAWORA T. Pluviothermal Conditions in Poland in Light of Contemporary Climate Change and Their Consequences for Agriculture and Water Management. Pol. J. Environ. Stud., 24, 1, 419, 2015.

39. LORENC H. The Atlas of the Climate of Poland. The Institute of Meteorology and Management, Warszawa, 2005 [In Polish].

40. TRNKA M., EITZINGER J., SEMERÁDOVÁ D., HLAVINKA P., BALEK J., DUBROVSKÝ M., KUBU G., ŠTEPÁNEK P., THALER S., MOŽNÝ M., ŽALUD Z. Expected Changes in Agroclimatic Conditions in Central Europe. Climatic Change, 108 (1-2), 261, 2011. 